Rakenteiden Mekaniikka (Journal of Structural Mechanics)

Vol. 50, Nro 4, 2017, s. 405-419

http://rakenteidenmekaniikka.journal.fi/index

https:/doi.org/10.23998/rm.64418

(CKirjoittaja(t) 2017.

Vapaasti saatavilla CC BY-SA 4.0 lisensioitu.

\title{
Kyntöauran rakenteiden kehittäminen mitatun kuormitusaineiston perusteella
}

\author{
Lassi Keränen
}

Tiivistelmä. Tutkimuksessa sovellettiin erilaisia lujuusopin ja standardien mukaisia käytössä olevia väsymismitoitusmenetelmiä hitsi -ja ruuviliitoksilla kokoonpantuun maatalouskoneen suunnitteluun ja lujuuslaskentaan. Tutkimuksessa mitattiin kyntöauran rakenteisiin kohdistuvia kuormituksia venymäliuskamittausten avulla ja analysoitiin rakenteiden käyttäytymistä auran käytön aikana. Mitattujen kuormitusten perusteella arvioitiin alkuperäisen S355-teräksestä valmistetun kyntöauran rakenneosien kestoikää. Auran runko-osat suunniteltiin uudelleen käyttäen S700-lujuusluokan rakenneputkea ja rakenneosille tehtiin väsymismitoitus mitattujen kuormitusten perusteella. Suunnitellun rakenteen mitoituksessa ja jännitysten laskennassa hyödynnettiin FE-menetelmää. Hitsaamalla liitettäviä osia oli muotoiltava uudelleen sallitun jännitystason saavuttamiseksi. Väsymismitoituksessa käytettiin lujuusopin mukaista yksinkertaistettua S-N -käyrää, väsymiskestävyyteen vaikuttavia tekijöitä ja lovenmuotolukuja sekä standardien mukaisia väsymisluokkiin perustuvia menetelmiä hitsiliitosten mitoituksessa. Tutkimuksen tuloksena huomattiin, että suurin vaikutus kestoikään on liitoksen geometrialla ja hitsisauman jälkikäsittelyllä. Lujaa terästä käyttämällä rakenteen massa väheni, kun rakenteen kestävyys samalla parani.

Avainsanat: lujuuslaskenta, väsymiskestävyys, hitsausliitos, ruuviliitos, S-N -käyrä, kyntöaura

Vastaanotettu 2.6.2017. Hyväksytty 6.11.2017. Julkaistu verkossa 14.12.2017.

\section{Johdanto}

Koneensuunnittelussa on tarkoituksena suunnitella osat ja rakenteet siten, että tuloksena on ennalta suunnitellusti ja turvallisesti toimiva laite tai rakenne. Tämä tavoite voidaan saavuttaa, kun suunnittelija kykenee laskemaan ja arvioimaan vauriotapaukset- ja olosuhteet jokaiselle komponentille niin, että vaurio on hallittavissa [1].

Koneilta ja laitteilta odotetaan yhä parempaa hyötysuhdetta, käyttöikää ja keveyttä. Näitä vaatimuksia täyttämään on kehitetty yhä lujempia teräksiä, jotka parantavat rakenteen kestävyyttä tai hyötysuhdetta sekä mahdollistavat suuremman hyötykuorman määrän. Tällaiset koneet valmistetaan usein hitsaamalla menetelmän tehokkuuden ansiosta. 
Hitsaus aiheuttaa väsymislujuuden menetystä erityisesti ultralujilla teräksillä, sillä lujuus on saavutettu lämpökäsittelyillä, esimerkiksi termomekaanisella valssauksella, joiden vaikutuksia hitsauksen aiheuttamat lämpösyklit heikentävät [2]. Ultralujien terästen hitsausliitoksille on olemassa väsymismitoitusmenetelmiä, kuten 4R-menetelmä, joka huomioi materiaalin lujuuden, jäännösjännitykset, jännityssuhteen ja paikallisen jännityksen väsymismitoituksessa [23]. Lujien konerakenteiden suunnitteluosaaminen on kuitenkin vielä osin puutteellista, ja sen vuoksi on tarpeen tutkia suunnittelussa huomioitavia seikkoja sekä olemassa olevien suunnitteluohjeiden ja standardien sopivuutta lujien konerakenteiden suunnitteluun.

Särön kasvunopeus on teräksen lujuudesta riippumatta lähes vakio [3]. Tällöin alkusärön sisältävä luja teräs murtuu käyttökelvottamaksi yhtä nopeasti kuin normaali teräs samalla kuormituksella. Tämän vuoksi erityisesti lujien hitsattujen teräsosien riittävä väsymiskestävyys edellyttää usein hitsin jälkikäsittelyä liitosgeometrian huolellisen suunnittelun lisäksi. Jälkikäsittelyllä pyritään lisäämään väsymiskestävyyttä parantamalla hitsin geometriaa, poistamalla mahdolliset alkusäröt tai aiheuttamaan hitsisauman viereisiin pintaosiin puristusjäännösjännitystä $[4,5]$.

Tässä artikkelissa esitetään kyntöauran rakenneanalyysiä ja rakenteen kriittisten kohtien uudelleen suunnittelua, kun kriittisten rakenteiden lujuus nostetaan myötölujuuteen $700 \mathrm{MPa} 355 \mathrm{MPa}$ :sta. Tutkimuksen tavoitteena on selvittää myötölujuudeltaan $700 \mathrm{MPa}$ rakenneputken soveltuvuutta väsyttävästi kuormitetun maatalouskoneen runkomateriaalina. Lisäksi tavoitteena on keventää rakennetta sekä pidentää sen kestoikää, sillä auran rungon kestävyydessä on aiemmin havaittu ongelmia.

Suunnittelun perusteena käytettiin alkuperäisen koneen käytön aikaisista venymäliuskamittauksista saatuja kuormituksia. Tutkimuksessa hyödynnettiin FEmenetelmää auran rakenteiden analysoinnissa ja nimellisen jännityksen, hot spot -jännityksen sekä perinteisen lujuusopin menetelmiä väsymislaskennassa. Tämän artikkelin pohjana on ollut 2016 tekemäni diplomityö Kyntöauran rakenteiden ja kuormitusten analysointi.

\section{Väsyminen}

Väsymisilmiössä materiaalin alkuviasta, kuten reiän reunasta tai hitsin viasta, kasvaa särö johtaen materiaalin lopulliseen murtumiseen. Väsyminen on vaihtelevan kuormituksen alaisissa koneissa tyypillinen vauriomuoto, sillä jopa 70-90 \% vaurioista johtuu materiaalin väsymisestä [6].

\section{Väsymismitoitus}

Perinteisessä lujuusopissa väsymiskestävyys määritetään teräksen murtolujuuden perusteella siten, että kiillotetun koesauvan väsymisraja on puolet sen murtolujuudesta [7]. Näin saatua jännitysamplitudiin $\sigma_{a}$ verrattavaa vaihtolujuuden arvoa $\sigma_{w}$ redusoidaan keskijännityksen, kappaleen koon, pinnanlaadun, pintakäsittelyn, ympäristötekijöiden tai lovenvaikutuslukujen vaikutuksilla. Vaikutuskertoimia on taulukoitu esimerkiksi lujuusopin kirjoihin. Väsymismitoitussuosituksissa jännitykseen perustuvia mitoitusmenetelmiä ovat nimellisen jännityksen, hot spot -jännityksen ja lovijännityksen menetelmät. Menetelmät perustuvat S-N -käyriin, jotka saadaan väsytyskokeista [8]. 
Nimellisen jännityksen menetelmässä mitoitus tehdään rakenneyksityiskohtaa vastaavan, kokeellisesti määritetyn S-N -käyrän perusteella. Menetelmä perustuu mitoitettavan yksityiskohdan nimellisen jännityksen laskentaan kimmoteorian mukaisesti. Tällöin tarkasteltavan rakenneyksityiskohtaa rasittavan nimellisen jännityksen, rakenneyksityiskohtaa vastaavan S-N -käyrän ja väsymisluokan perusteella voidaan arvioida kyseisen kohdan kestoikää. Monimutkaisemmissa liitosmuodoissa mitoitusta voi kuitenkin rajoittaa tilanteeseen sopivien ja luotettavien S-N -käyrien puutteet ja mitoituksessa joudutaan tekemään yksinkertaistuksia. Nimellisen jännityksen menetelmässä sovellettavat S-N -käyrät voidaan laskea kaavalla (3) tai (4). [7, 15, 17, 18]

Hot spot -menetelmässä hitsausliitoksille tarvitaan vain yksi S-N -käyrä kuormitustyypeittäin, koska hitsisauman kriittisimmän kohdan geometria oletetaan samaksi liitostyypistä riippumatta. Hot spot-jännitys sisältää kaikki jännitystä rakenneyksityiskohdassa kasvattavat tekijät, lukuun ottamatta epälineaarisia, esimerkiksi hitsin reunan aiheuttamia jännityspiikkejä. Jännitykset voidaan määrittää mittaamalla vähintään kahdella venymäliuskalla venymät ja lineaarisesti ekstrapoloimalla venymä hitsin reunaviivalle hot spot -venymäksi ja jännitykseksi, FE-menetelmällä ja ekstrapoloinnilla tai käyttäen kirjallisuudesta löytyviä jännityskonsentraatiokertoimia ja rakenneyksityiskohdasta mitattua tai laskettua nimellisjännitystä. Venymäliuskoilla tapahtuvan hot spot-jännityksen määrityksessä venymäliuskojen etäisyydet hitsin rajaviivasta ovat tyypillisesti 0,4 ja yksi -kertaiset tarkasteltavan liitoslevyn vahvuudesta. Hot spot -menetelmässä ja muissa standardien mukaisissa menetelmissä käytettävät S-N -käyrät voidaan määrittää kaavoilla (9-12). [8, 15, 17]

Kuvassa 1 esitetään lujuusopin mukainen yksinkertaistettu nimellisen jännityksen S-N -käyrä kaavojen (1), (2) ja (3) mukaisesti 355-lujuusluokan teräkselle. Kuvassa 1 esitetään myös kaavojen (11) ja (12) mukainen käyrä, joka on laskettu EC 3:n [17] mukaisella suurimmalla sallitulla väsymisluokalla 160. EC 3:n mukaan tämä on suurin sallittu väsytysluokka myös perusaineelle. Väsymiskestävyyttä pienentävien tekijöiden vaikutuksia ei ole huomioitu. Kuvaa tarkasteltaessa on huomioitava, että yksinkertaistetun S-N -käyrän laskennassa käytetään jännitysamplitudia ja EC 3:n käyrälle jännityksen vaihteluväliä.

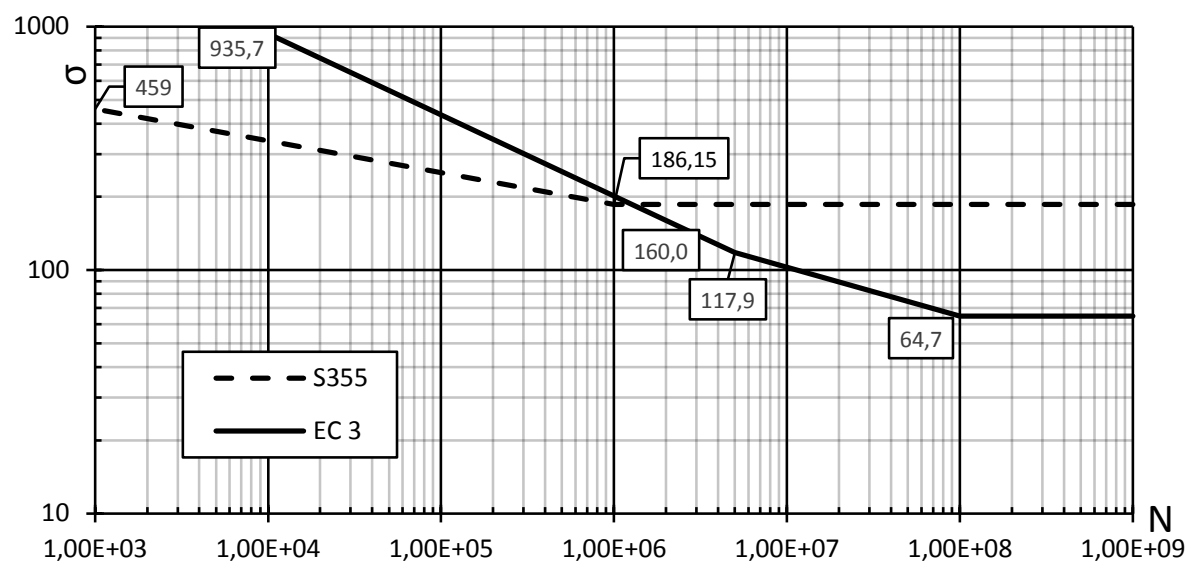

Kuva 1. S-N -käyrät yksinkertaistetulla ja Eurokoodin mukaisella tavalla S355 -teräkselle perusaineen mitoitukseen. 
Lujuusopin mukaisessa mitoituksessa käytettävä yksinkertaistettu S-N -käyrä saadaan käyttämällä kestorajaa $\sigma_{1000}$ syklimäärän $10^{3}$ kohdalla, mikä saadaan kaavalla

$$
\sigma_{1000}=0,9 * R_{m},
$$

missä $\sigma_{1000}$ on kestoraja ja $R_{m}$ on murtolujuus. Käyrän toinen piste on vaihtolujuus syklimäärällä $10^{6}$, mikä saadaan kaavalla

$$
\sigma_{w}=0,5 * R_{m} .
$$

Vaihtolujuutta $\sigma_{w}$ vastaavasta syklimäärästä eteenpäin käyrä on vaakasuora kaksoislogaritmisessa asteikossa. S-N -käyrän yhtälö välillä $10^{3} \ldots 10^{6}$ on tässä tapauksessa

$$
\log \left(\sigma_{a}\right)-\log \left(\sigma_{1000}\right)=\frac{\log \left(\sigma_{w}\right)-\log \left(\sigma_{1000}\right)}{\log \left(10^{6}\right)-\log \left(10^{3}\right)} *\left[\log (N)-\log \left(10^{3}\right)\right],
$$

missä $N$ vastaa kestoikää jännitysamplitudilla $\sigma_{a}$. Kun edellinen yhtälö sievennetään, saadaan yleinen muoto

$$
N=10^{-\alpha / b} * \sigma_{a}^{1 / b},
$$

missä $\alpha=\log \left(\sigma_{1000}{ }^{2} / \sigma_{\mathrm{w}}\right)$ ja $\mathrm{b}=-1 / 3 \log \left(\sigma_{1000} / \sigma_{\mathrm{w}}\right)$. Vaihtolujuuden maksimiarvo on $700 \mathrm{MPa}$, mitä käytetään murtolujuuden ollessa yli $1400 \mathrm{MPa}$. [7]

Keskijännitys voi kuitenkin poiketa nollasta merkittävästi. Hitsatuissa liitoksissa keskijännitykseen vaikuttaa ulkoisen kuormituksen lisäksi useissa tutkimuksissa havaittu jopa lähes myötölujuuden suuruinen vetojäännösjännitys, mutta ultralujilla teräksillä jäännösjännitys voi olla osittain myös puristavaa [9-12, 24]. Jotta lujalla teräksellä saavutettavat edut saadaan hyödynnettyä maksimaalisesti myös hitsiliitoksissa, on hitsisaumat oltava erittäin hyvälaatuisia. Nämä laatuvaatimukset saavutetaan järkevimmin hitsisauman jälkikäsittelyllä. Lujalle teräkselle soveltuvia menetelmiä ovat esimerkiksi hitsin reunaviivan hionta, TIG-käsittely, kuulapuhallus, vasarointi ja esiylikuormitus [4, 8]. Uusimpana menetelmänä on HFMI-käsittely, mikä on käytännössä hyvin korkeataajuista hitsin reunan vasarointia [13]. Taulukossa 1 verrataan eri jälkikäsittelymenetelmillä saavutettuja hitsiliitosten karakteristisia väsymisluokkia käsittelemättömiin, standardien mukaisiin karakterististen väsymisluokkien arvoihin. Nämä arvot soveltuvat hitsiliitoksille myötölujuuteen 900 MPa saakka, mutta HFMIkäsittelyllä saavutettavat arvot soveltuvat kuitenkin myös myötölujuuden $960 \mathrm{MPa}$ teräksille [2, 4, 13].

Todellisissa tilanteissa kuormitus on usein vaihtuva-amplitudista, jolloin edellä mainittuja, vakio-amplitudisiin kokeisiin perustuvia menetelmiä on vaikea soveltaa. Tällaisissa tilanteissa on käytettävä esimerkiksi Palmgren-Minerin sääntöä

$$
D=\frac{N_{1}}{N_{f 1}}+\frac{N_{2}}{N_{f 2}}+\cdots=\sum \frac{N_{j}}{N_{f j}}=1,
$$

missä $D$ on suhteellinen vaurioaste ja $N_{i}$ on jännitystasoa $N_{f i}$ vastaavien kuormituskertojen määrä $[14,15]$. Tarkastelujakson kuormituskerojen määrän ja vaurioasteen avulla saadaan selville murtumaan johtavien kuormituskertojen lukumäärä $N$ kaavalla [15]

$$
N=\frac{\sum N_{j}}{D} \text {. }
$$


Kyseisessä säännössä ajatellaan vaurion syntyvän silloin, kun osavaurioiden summa on yksi. Myös muita sovelluskohtaisia arvoja voidaan käyttää. Kuormituskertojen määrä selvitetään tällöin esimerkiksi Rainflow-menetelmällä, millä ajan suhteen mitatusta jännitys -tai venymähistoriasta erotetaan amplitudit, niiden määrät ja keskiarvot [16]. Myös Eurokoodi 3:n [17] väsymisosio ja vanhempi standardi SFS 2378 [18] väsyttävästi kuormitettujen hitsausliitosten mitoituksesta ohjaavat Rainflow-menetelmän ja Palmgren-Minerin säännön käyttämiseen vaihtuva-amplitudisessa kuormituksessa.

Useimmissa tilanteissa tarkkaa jännitysvaihteluvälin kertymää ei tiedetä, jolloin mitoitus voidaan tehdä standardin SFS 2378 tyypitettyjen kertymien mukaisesti ekvivalentilla jännitysheilahduksella

$$
\Delta \sigma_{e q}=\psi * \Delta \sigma_{\max }
$$

missä $\Delta \sigma_{e q}$ on ekvivalentti jännitysheilahdus, $\psi$ on kertymäkerroin ja $\Delta \sigma_{\max }$ on jännitysheilahduksen maksimi. Kertymäkerroin valitaan mitoitettavan yksityiskohdan vaatimusten ja kuormituskertymän muodon perusteella standardin taulukoista tai lasketaan kaavalla

$$
\psi=\sqrt[3]{\frac{\sum_{i=1}^{k}\left(\frac{\Delta \sigma_{i}}{\Delta \sigma_{\max }} * n_{i}\right)}{5 * 10^{6}}},
$$

missä $\Delta \sigma_{i}$ on vaihteluväli, $\Delta \sigma_{\max }$ on vaihteluvälin jännityksen maksimi ja $n_{i}$ on jännitysjaksojen määrä vaihteluvälillä. [18]

Hitsiliitoksen väsymismitoitus tehdään standardeissa ja IIW:n suosituksissa [8] esitettyjen liitosmuotojen ja rakenneyksityiskohtien mukaisten väsymisluokkien perusteella $[17,18]$.

Taulukko 1. Hitsin jälkikäsittelyn vaikutukset karakteristiseen väsymisluokkaan [2].

\begin{tabular}{lllll}
\hline Liitosmuoto & Menetelmä & $\begin{array}{l}\text { Jälkikäsitelty } \\
\text { väsymisluokka }\end{array}$ & $\begin{array}{l}\text { Alkuperäinen } \\
\text { väsymisluokka }\end{array}$ & Vaikutuskerroin \\
\hline Päittäisliitos & TIG & $180-205$ & 90 & $2-2,3$ \\
& Kuulapuhallus & 225 & & 2,5 \\
& Vasarointi & 190 & 2,1 & 2 \\
\hline Ristiliitos & HFMI & 180 & 71 & $1,8-2,2$ \\
& TIG & $125-155$ & & 2,3 \\
& Hionta & 160 & & 2,0 \\
& Kuulapuhallus & 145 & & 3 \\
& Vasarointi & 210 & $71-90$ & 2 \\
\hline \multirow{2}{*}{ T-Liitos } & HFMI & 140 & & $1,7-1,3$ \\
& TIG & 120 & $63-71-90$ & 2,4 \\
\hline \multirow{2}{*}{ Pitkittäinen ripa } & Kuulapuhallus & 220 & & $1,1-1,4-1,6$ \\
& Hionta & 100 & & $1,1-1,9$ \\
& Kuulapuhallus & $95-120$ & $1,1-1,4-1,6$ \\
& Vasarointi & 100 & $1,3-2,8$ \\
\hline
\end{tabular}


Väsymisluokka $\Delta \sigma_{C}$ tarkoittaa väsymislujuuden arvoa kahden miljoonan syklin kohdalla ja perustuu täyden mittakaavan väsytyskokeisiin. Standardien väsymisluokkia käytettäessä käytetään myös sitä vastaavaa S-N -käyrää. Standardin EC3 soveltaminen on sallittua enintään lujuusluokissa S690 kuumavalssattuna, S700 kylmämuovatuilla muotosauvoilla -ja levyillä ja S960 erityisehtoja noudattaen [21]. Eurokoodin [17] mukainen kaksoislogaritminen S-N -käyrä saadaan vakioamplitudisen väsymisrajan $\Delta \sigma_{D}$ avulla syklimäärällä $5^{*} 10^{6}$ ja alemman väsymisrajan $\Delta \sigma_{L}$ avulla syklimäärällä $10^{8}$, kun

$$
\begin{gathered}
\Delta \sigma_{D}=0,737 * \Delta \sigma_{C} \text { ja } \\
\Delta \sigma_{L}=0,549 * \Delta \sigma_{D} .
\end{gathered}
$$

Tällöin $\Delta \sigma_{R}$ jännitystasoa vastaava kuormituskertojen määrä $N_{R}$ saadaan vakioamplitudisen väsymisrajan yläpuolella kaavasta

$$
\Delta \sigma_{R}^{m} * N_{R}=\Delta \sigma_{C}^{m} * 2 * 10^{6},
$$

missä $m$ kuvaa käyrän kaltevuutta ja on 3. Vakioamplitudisen väsymisrajan ja alemman väsymisrajan välillä $(m=5)$ vastaava kuormituskertojen määrä saadaan kaavasta

$$
\Delta \sigma_{R}^{m} * N_{R}=\Delta \sigma_{D}^{m} * 5 * 10^{6} .
$$

Mitoitusprosessia voidaan kuvata seuraavasti. Koneelle suunnitellun käyttömäärän perusteella tiedetään liitoksen kuormanvaihtokertojen määrä aikayksikköä kohti, jolloin suunniteltu käyttöikä voidaan määrittää. Rakenne on suunniteltu muilta osin valmiiksi, joten hitsausliitoksen muoto ja väsymisluokka tiedetään. Seuraavaksi voidaan todeta, että liitokselta vaaditaan suurta varmuutta ja liitos on jälkikäsiteltävä. Uusi väsymisluokka $\Delta \sigma_{C}$ saadaan taulukon 1 mukaisesti. Myös liitoksen kuormitusten suuruus ja määrä tunnetaan, joten ekvivalentti jännitysheilahdus $\Delta \sigma_{e q}$ voidaan määrittää kaavoilla (7) ja (8). Tämän tulee olla väsymisluokkaa pienempi, jotta mitoitusehto, kaava (11) tai (12), sekä haluttu kestoikä täyttyvät. [2]

Jos mitoitettava yksityiskohta on esimerkiksi perusaineessa oleva reikä, mitoitus tehdään perinteisen lujuusopin mukaisesti pienennyskertoimia käyttäen. Tällöin kuormitusta vastaavan syklimäärän on oltava pienempi kuin kaavalla (3) lasketun syklimäärän, jotta suunniteltu käyttöikä toteutuu. [2]

\section{Esimerkkitapaus kyntöaura}

Tutkittava kyntöaura on nelisiipinen kääntöaura, jonka alkuperäisenä rakennemateriaalina on käytetty S355-lujuusluokan terästä. Tutkimuksessa määritetään rakenteisiin kohdistuvat käytönaikaiset kuormitukset venymäliuskamittauksella, jotta uuden rakenteen suunnittelu todellisia kuormituksia käyttäen on mahdollista. Lisäksi tutkimuksessa verrataan rakenteiden kestoikiä ja massoja kun runkorakenteiden materiaali on vaihdettu S700-teräkseen. Tällä teräsrakenneputkella myötölujuus on vähintään $700 \mathrm{MPa}$ ja murtolujuus 750-950 MPa [22].

\section{Kuormitusten määritys}

Kyntöauraan kohdistuvat kuormitukset määritettiin venymäliuskamittauksella sijoittaen mittausalueet auran alku- ja loppupäihin, päärunkoon ja auran ensimmäiseen ja 
viimeiseen siiven runkoon. Tällöin saatiin erotettua siipikohtaiset kuormitukset, taulukko 2. Mittausalueet ja voimien suunnat esitetään kuvassa 2. Runkoputkissa käytettiin yksisuuntaisia venymäliuskoja normaalijännityksen mittaamiseen ja siipien kannattimen ja apurunkoputken välisestä hitsisaumasta mitattiin hot spot -jännitystä 3-suuntaisilla rusettiliuskoilla. Mittaukset suoritettiin siten, että tavanomaiset kuormitukset mitattiin suoraviivaisen liikkeen aikana ja satunnaiset maksimikuormitukset suunnanmuutoksen aikana kivien osumia simuloiden. Mittaukset tehtiin mittalaitteiden sijoittelun vuoksi käyttämällä vain auran toista puolta, jolloin kuormitus näyttää vetotykytyskuormitukselta. Todellisessa tilanteessa auraa käännetään, jolloin kuormitus on vaihtokuormitusta ja keskijännitys on lähellä nollaa. Tällöin keskijännityksen vaikutuksia väsymiskestävyyteen ei tarvitse erikseen huomioida laskennassa ja voidaan käyttää mittauksista saatua aineistoa.

Mitatun aineiston pohjalta laskettiin jännitysvaihtelut jokaisen venymäliuskan ja rungon maksimijännityksen kohdalla. Päärunkoputken maksimijännitysheilahdus $129 \mathrm{MPa}$ havaittiin viimeisen siiven kiinnittimen kohdalla rungon alapuolelta. Siipien runkojen maksimijännitysheilahdukset 295 MPa ja 220 MPa havaittiin ensimmäisen ja viimeisen siiven runkoputken alapuolella. Hitsisaumojen hot spot -jännitysheilahduksen maksimit ovat vastaavasti $398 \mathrm{MPa}$ ja $254 \mathrm{MPa}$. Maksimijännitysten perusteella laskettiin jokaiseen siipeen kohdistuvat ulkoisten voimien maksimit (taulukko 2), joita myöhemmin käytetään uuden rakenteen suunnittelussa.

Kyntöaurasta luotiin kuvan 3 mukainen FE-malli, joka validoitiin edellä laskettujen voimien avulla. Tällöin nämä voimat tuottivat malliin alkuperäisistä jännityksistä 0-15 \% eroavat jännitykset laskentapisteestä riippuen. Mallia voidaan siten käyttää uuden rakenteen suunnittelussa, kun ulkoisia kuormituksia korotetaan ja käytetään riittävää varmuuskerrointa.

Taulukko 2. Auran siipiin vaikuttavat ulkoiset voimat.

\begin{tabular}{lllll}
\hline siipi/voima & 1 & 2 & 3 & 4 \\
\hline $\mathrm{F}_{\mathrm{I}}[\mathrm{kN}]$ & 19,1 & 17,3 & 15,5 & 13,7 \\
\hline $\mathrm{F}_{\mathrm{T}}[\mathrm{kN}]$ & 23,1 & 19,5 & 15,9 & 12,3 \\
\hline
\end{tabular}

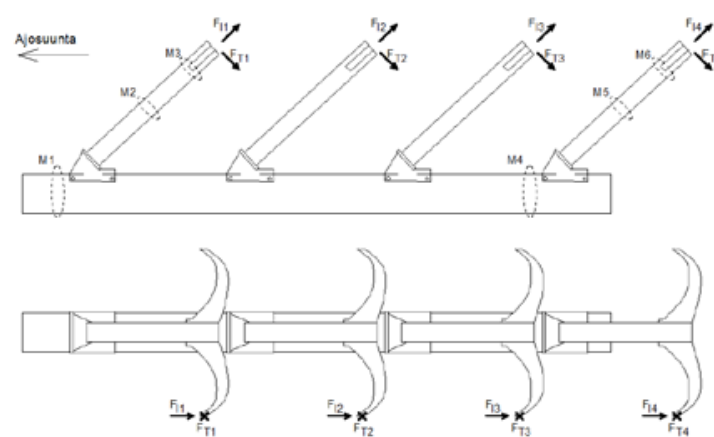

Kuva 2. Periaatekuva voimien suunnista ja mittausalueista M1-M6.

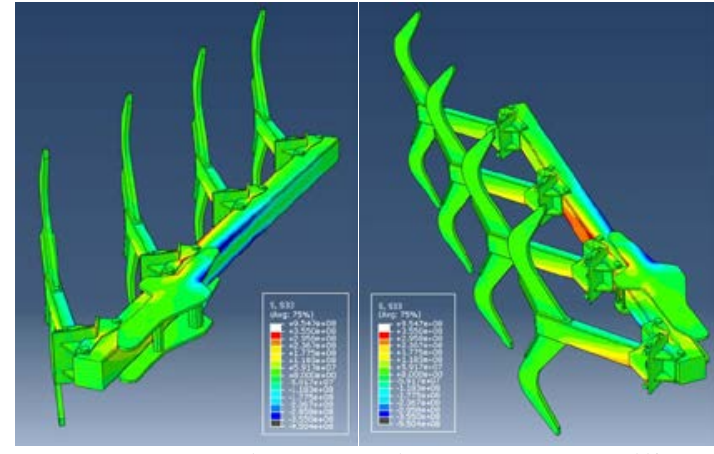

Kuva 3. Laskennassa käytetty FE-malli. 


\section{Alkuperäisen rakenteen kestoikätarkastelu}

Mitatusta venymähistoriasta laskettiin jännitykset kestoikätarkastelun tekemiseksi. Kriittisille rakenteen osille, kuten vetojännityksen alaisille ruuvin rei'ille ja hitsisaumoille tehtiin kestoikälaskelmat käyttäen Rainflow-menetelmää, Palmgren-Minerin sääntöä ja EC3 sekä SFS 2378 mukaisia S-N -käyriä, väsymisluokkia ja kertymiä.

Tarkastellaan esimerkkitapauksina siivenkannattimen ja apurungon välistä hitsiliitosta, kuva 4 kohta 1, sekä päärunkoa siinä olevan ruuvinreiän kohdalta, kuva 4 kohta 4. Kuvassa 4 esitetään myös muut tutkitut rakenneyksityiskohdat ja mahdolliset särösuunnat. Näiden kriittisten yksityiskohtien suhteelliset jännitysspektrit esitetään kuvassa 5. Jännitysvaihteluvälien- ja amplitudien perusteella määritetään alkuperäisen rakenteen laskennalliset kestoiät, joihin suunniteltavan rakenteen kestoikiä myöhemmin verrataan. Hot spot -menetelmällä tarkastettiin rakenneyksityiskohta 1 ja nimellisellä jännityksellä yksityiskohdat 2-4.

Rakenneyksityiskohdan 1 hot spot -jännityksen väsytysluokaksi $\Delta \sigma_{C}$ valitaan $100 \mathrm{MPa}$ liitosmuodon perusteella, jolloin vakioamplitudinen väsymisraja $\Delta \sigma_{D}$ kaavan (9) mukaisesti on $73,7 \mathrm{MPa}$ ja alempi väsymisraja $\Delta \sigma_{L}$ kaavan (10) mukaisesti on 40,5 MPa. Tätä pienempien jännitysvaihteluiden ei oletettu kasvattavan vauriota. Kaavojen (3), (11) ja (12) mukaisesti lasketaan jokaista jännitysvaihteluväliä -ja amplitudia vastaavat kuormituskerrat sekä kaavalla (5) vauriosummat. Tällöin hot spot -kohdan ja reiän vauriosummat $D$ ovat 0,0029 ja 0,00021 , joista saadaan kaavalla (6) murtumaan johtavien kuormituskertojen määräksi vastaavassa järjestyksessä $3,5 * 10^{2}$ ja $3,3 * 10^{7}$ kuormanvaihtoa.
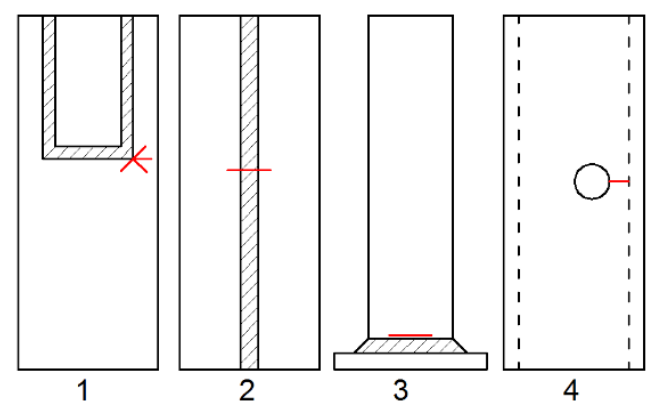

Kuva 4. Tutkittavat rakenneyksityiskohdat, joista 1,2 ja 3 ovat hitsausliitoksia ja 4 on ruuviliitos.
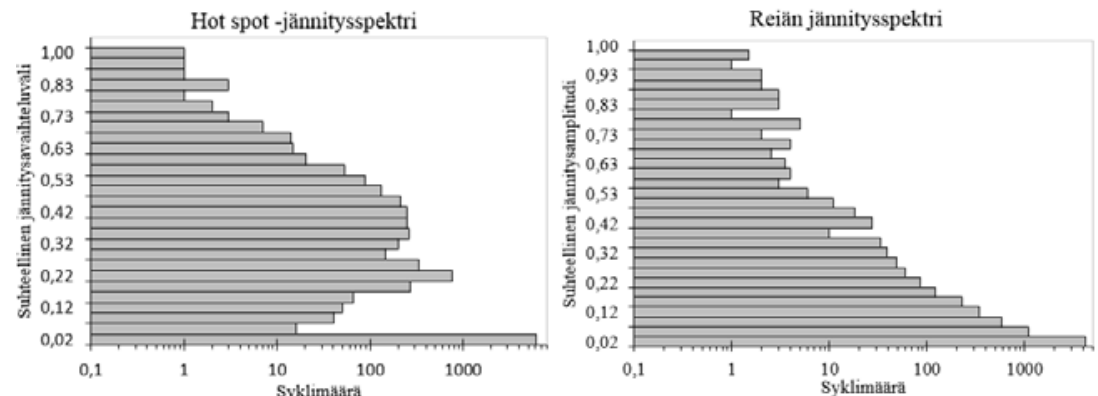

Kuva 5. Kriittisten rakenneyksityiskohtien suhteelliset jännitysspektrit. 
Rakenneyksityiskohdassa 4 ruuveilla kiinnitetään U-muotoinen kotelo runkopalkin ympärille. Yksityiskohdan mitoituksessa reiän vaikutus huomioidaan korottamalla reiän kohdalla olevan ehjän materiaalin nimellistä jännitystä lovenvaikutusluvulla 1,8 ja pienennetään vaihtolujuutta pinnanlaadun vaikutuksella 0,65 . Tällöin saadaan auran arvioidun käyttömäärän perusteella kestoi’iksi hitsiliitokselle 0,7 ja päärungolle ruuvinreiän kohdalla 25 työvuotta. Samalla tavalla lasketaan myös muiden yksityiskohtien kestoiät, jotka ovat apurungon pitkittäishitsille (kuva 4 kohta 2) 2,2 vuotta, apurungolle 999 vuotta ja apurunko-päärunko -liitokselle (kuva 4 kohta 3) 17,5 vuotta. Päärungon pitkittäishitsi on puristuspuolella, joten sen ei oleteta olevan väsyttävästi kuormitettu.

\section{Uuden rakenteen suunnittelu}

Uusi runkorakenne suunnitellaan S700-lujuusluokan rakenneputkesta siten, että päärunko ja apurungot ovat poikkileikkauksiltaan $150 \times 150 \times 4,5 \mathrm{~mm}^{3}$ ja $75 \times 140 \times 5 \mathrm{~mm}^{3}$. Alkuperäisessä rakenteessa nämä mitat olivat 150 x $150 \times 6 \mathrm{~mm}^{3}$ ja 70 x $140 \times 8 \mathrm{~mm}^{3}$. Aloitetaan uuden rakenteen tarkastelu vaihtamalla FE-mallissa alkuperäiset rungot edellä mainituiksi profiileiksi ja tarkastelemalla rakenteen kriittisten kohtien jännityksiä.

Apurungon maksimijännityksen suuruudeksi saadaan FE-mallista $546 \mathrm{MPa}$, mikä vastaa riittävää 1,28 varmuuskerrointa myötölujuuteen $700 \mathrm{MPa}$ verrattuna. Apurungon hitsin hot spot -jännitys on $780 \mathrm{MPa}$, mikä on liian suuri myötölujuuteen verrattuna. Apurungon ja siivenkannattimen välisen hitsisauman hot spot -jännitys on $743 \mathrm{MPa}$, joka on myös liian suuri. Päärungon maksimijännitys on 530 MPa vastaten 1,32 varmuutta, mikä on hyväksyttävä. Apurungon kiinnityksen ruuvinreiän jännitys on $353 \mathrm{MPa}$ tarkoittaen riittävää 1,98 varmuutta.

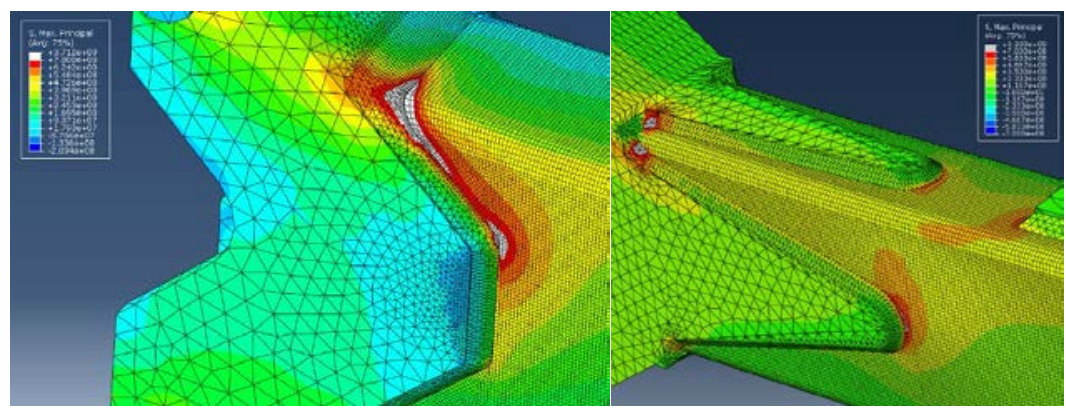

Kuva 6. Vasemmalla alkuperäinen ja oikealla uusi apurungon kiinnitys (detalji 3).

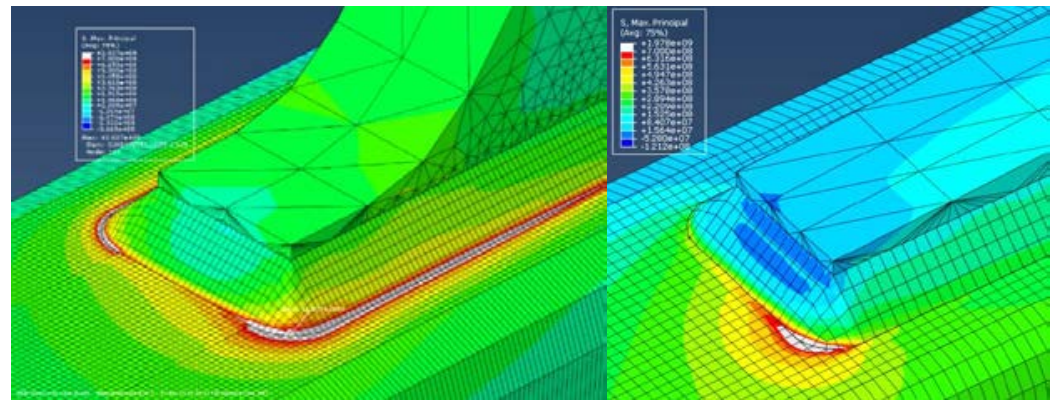

Kuva 7. Vasemmalla alkuperäinen ja oikealla uusi siiven kannattimen kiinnitys (detalji 1). 
Suunnitellaan heikot rakenteiden liitokset uudelleen, jotta saavutetaan riittävä varmuus staattisessa mitoituksessa. Muutetaan apurungon kiinnityksen geometriaa siten, että kiinnityslevyt kapenevat rungon neutraaliakselia kohti kuvassa 6 esitetyllä tavalla. Tällöin hot spot -jännitykset ovat $485 \mathrm{MPa}$ ja $637 \mathrm{MPa}$ palkin kapealla ja leveällä sivulla vastaten varmuuskertoimia 1,44 ja 1,1. Myös apurungon ja siiven kannattimen liitosta on muutettava, jotta saavutetaan riittävä varmuus. Suunnitellaan tähän hitsiliitos, missä hitsisauman pituus kaksinkertaistetaan, kuva 7. Tällöin hot spot -jännityksen maksimi on $617 \mathrm{MPa}$, jolla saadaan 1,35 varmuuskerroin.

\section{Hitsausliitosten mitoitus}

Lasketaan edellä suunnitelluille hitsiliitoksille minimimitat, jotta myös hitsisauma on riittävä. Lämmöntuonnin perusteella pienahitsin a-mitan $a$ on oltava kaavan (13) mukainen

$$
a \geq \sqrt{\frac{t}{m m}}-0,5 m m,
$$

missä $t$ on liitettävän rakenneosan paksuus. Lisäksi a-mitan on oltava lämmöntuonnin ja jäähtymisnopeuden perusteella välillä

$$
3 \mathrm{~mm} \leq a \leq 15 \mathrm{~mm} \text {. }
$$

Yksinkertaisessa laskentatavassa a-mitta lasketaan perustuen nimelliseen jännitykseen $\sigma_{n w}$. Tällöin jännitys oletetaan mahdollisimman epäedulliseksi ulkoisten voimien suunnista riippumatta ja lasketaan kaavalla

$$
\sigma_{n w}=\frac{F}{a * l} \leq\left\{\begin{array}{c}
\frac{f_{d}}{\beta * \sqrt{3}} \\
\frac{f_{u}}{\beta * \sqrt{3} * \gamma_{m w}}
\end{array},\right.
$$

missä $F$ on ulkoinen voima, $l$ hitsin pituus, $f_{d}$ perusaineen mukainen sallittu jännitys, $\beta$ perusaineen ja hitsin lujuuksien suhdeluku, $f_{u}$ perusaineen murtolujuus ja $\gamma_{m w}$ on osavarmuusluku. [15]

Arvioidaan sallitun jännityksen arvo S700-teräkselle lähteessä [15] esitettyjen S235...S460 -terästen leikkauslujuuksien perusteella lineaarisella sovituksella sekä kaavan (15) mukaisesti. Tällöin saadaan leikkauslujuuksien arvot $336 \mathrm{MPa}, 404 \mathrm{MPa}$ ja 346 MPa. Käytetään mitoituksessa konservatiivisinta arvoa $336 \mathrm{MPa}$. Tällöin kaavojen (13), (14) ja (15) mukaisesti saadaan apurungon ja siivenkannattimen väliselle $800 \mathrm{~mm}$ pitkälle hitsille a-mitaksi 3 mm, kun liitokseen vaikuttavat voimat ovat 19,1 ja 23,1 kN ja hitsi on tasaluja. Myös apurungon kiinnittimen hitsisaumojen a-mitaksi saadaan $3 \mathrm{~mm}$, kun hitsiä on yhteensä $1500 \mathrm{~mm}$.

\section{Ruuviliitosten mitoitus}

Apurunko kiinnitetään päärunkoon kahdella ruuvilla alkuperäisen rakenteen mukaisesti, missä ruuvit ovat $288 \mathrm{~mm}$ etäisyydellä toisistaan, kuva 8. Käytetään ruuveina M24 ruuveja, jotka ovat $30 \mathrm{~mm}$ etäisyydellä levyn reunoista. Kun ruuviliitos suunnitellaan täysin kitkaliitoksena, ruuviin kohdistuu vain esijännitysvoima, jolloin ruuvin kestävyys ei vaikuta liitoksen väsymiskestävyyteen. Esikiristysvoiman on oltava liitoksen 
leikkausvoimaa suurempi, jotta liitos toimii oikein. Vääntö -ja leikkauskuormitetun ruuviryhmän kokonaisleikkausvoima $Q_{k}$ saadaan kaavalla

$$
Q_{k}=\frac{2 * T}{z * d_{t}}+\frac{F_{t}}{z}
$$

missä $T$ on liitoksen vääntömomentti, $z$ on ruuvien lukumäärä, $d_{t}$ on ruuvien jakohalkaisija ja $F_{t}$ on liitokseen kohdistuva leikkausvoima [15]. Kun liitoksessa vaikuttaa leikkausvoima 19,1 kN ja vääntömomentti 17,3 kNm, liitosta kuormittaa kokonaisleikkausvoima 69,6 kN. Tällöin tarvittava ruuvin esikiristysvoima kitkakertoimella 0,3 on vähintään 232 kN. Lujuusluokan 10.9 M24 ruuvit riittävät, sillä niillä saavutettava esikiristysvoima on $240 \mathrm{kN}$ [20]. Kitkaliitoksena mitoitettu ruuviliitos voidaan olettaa olevan lähes täysin väsymätön, kun huolehditaan liitoksen pysymisestä kireänä. Tarkasteltavassa tilanteessa ruuvien pysyminen kireänä voi olla epävarmaa, sillä ruuvi kulkee joustavan rakenneputken lävitse ja esikiristysvoima voi jäädä riittämättömäksi. Tästä syystä ruuvien kireänä pysymistä varmistetaan jousialuslaatoilla. Mikäli ruuvit kuitenkin löystyvät, kuormitus kohdistuu runkopalkin laippojen alueelle, jolloin nettopoikkileikkauksen pinta-ala on vähintään $8 \%$ koko poikkileikkauksesta. Tässä tapauksessa vetojännitys on 639 MPa vastaten varmuuskerrointa 1,1.

\section{Väsymismitoitus}

Rakenneputkien väsymisluokat perustuvat mitattuihin [19] väsymisluokkiin. Tutkitut poikkileikkaukset olivat $160 \times 160 \times 4 \mathrm{~mm}^{3}$ ja 120 × 120 × $4 \mathrm{~mm}^{3}$, jotka olivat S700-lujuusluokkaa. Putkissa vauriot alkoivat pääsääntöisesti putken ulkopinnalta ja väsytysluokkien keskiarvoksi vetotykytyksellä saatiin $188 \mathrm{MPa}$ [19], mikä on standardien mukaista $[17,18]$ perusaineen väsymisluokan maksimia suurempi. Käytetään tätä arvoa runkoputkien pitkittäishitsien väsymismitoituksessa.

Maksimijännitykset vastaavat kuormitusmittausten perusteella kiven osumista auraan, mikä tapahtuu keskimäärin kerran 1,33 tunnissa ja on 1,35-kertainen tavanomaiseen kuormitukseen verrattuna. Tavanomaisia kuormanvaihtoja on 26 kappaletta 1,33 tunnin aikana ja auran suunniteltu käyttöikä on 15 vuotta. Tavanomainen kuormanvaihto oletetaan olevan sillä välillä, kun aura lasketaan maahan pellon alussa ja nostetaan ylös sen lopussa. Mitoituksessa käytetään varmuuskerrointa 1,25. Kaavan (11) avulla etsitään jokaisen kuormitustapauksen maksimijännitykselle syklimäärä, jonka alapuolella staattinen mitoitus on määräävänä.

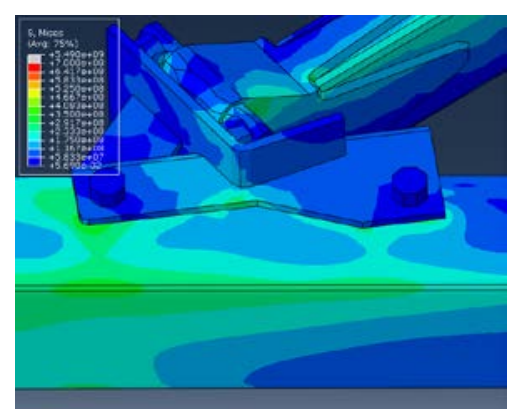

Kuva 8. Apurungon ja päärungon välinen ruuviliitos 
Tämän perusteella väsymismitoitus tehdään vain tavanomaisella kuormituksella, sillä kivien osumisessa staattinen mitoitus on määräävänä.

Tarkastellaan myös uuden rakenteen suunnittelussa esimerkin omaisesti siivenkannattimen ja apurungon välistä hitsiliitosta hot spot -jännityksellä sekä päärungon ruuvinreikää nimellisellä jännityksellä mitoitettuna. Mikäli hitsien väsymisluokka osoittautuu riittämättömäksi, korotetaan väsymisluokkaa jälkikäsittelyllä. Jälkikäsittelymenetelmät valitaan siten, että ne on mahdollista suorittaa tavanomaisessa valmistavassa konepajassa kohtuullisin lisäkustannuksin hitsaukseen verrattuna. Tämän perusteella valitaan käytettäviksi jälkikäsittelymenetelmiksi reunahaavan hionta tai hitsin kuulapuhallus, jotka voidaan tehdä esimerkiksi rakenteiden pintakäsittelyn yhteydessä tavanomaista konepajavarustusta hyödyntäen.

Apurungon ja siivenkannattimen välisen hitsin hot spot -jännitys on $457 \mathrm{MPa}$ [2] ja väsymisluokka on taulukoiden mukaan [17] $100 \mathrm{MPa}$, jota tässä tilanteessa korotetaan kuulapuhalluksella tai reunahaavan hionnalla. Tällöin pitkittäisen rivan väsymisluokka paranee 1,33-kertaiseksi taulukon 1 perusteella ollen siis $133 \mathrm{MPa}$. Käytetään kertymää 0,233 [18] ja varmuuskerrointa 1,25. Tällöin ekvivalentti jännitysheilahdus 132,9 MPa saadaan kaavalla (7). Verrataan tätä arvoa väsymisluokkaan, jolloin käyttöaste on 99,9 \%, vastaten 20 vuoden kestoikää vuosittainen käyttö ja varmuuskerroin huomioiden. Kestoikä lasketaan kaavoilla (9), (10), (11) ja (12) käyttö -ja syklimäärän perusteella.

Päärungon maksimijännitysamplitudi ruuvinreiän kohdalla on 294,2 MPa [2] lovenmuotoluvulla 1,8 ja varmuuskertoimella 1,25 korotettuna. Kaavojen (1), (2) ja (3) perusteella kestoiäksi saadaan siten 25 vuotta, kun myös pinnanlaadun vaikutuskerroin 0,55 huomioidaan vaihtolujuutta vähentäen.

Myös muille rakenneyksityiskohdille tehdään väsymismitoitus vastaavalla tavalla. Runkoputkien pitkittäishitseillä käytetään väsymisluokkaa $188 \mathrm{MPa}$, mutta hitsin jälkikäsittelyä ei huomioida. Muille hitsausliitoksille käytetään lähteessä [17] taulukoituja väsymisluokkia ja hitsauksen jälkikäsittelyn vaikutuksia taulukosta 1 edellä valittujen jälkikäsittelymenetelmien mukaisesti. Reikien ja muiden hitsaamattomien kohtien mitoitus tehdään lujuusopin menetelmien mukaisesti. Tällöin apurungon pitkittäishitsin kestoikä on 101 työvuotta, apurungon ehjän poikkileikkauksen käyttöikä 62 vuotta sekä apurungon ja päärungon välisen hitsisauman kestoikä 81 työvuotta. Päärungon reiän kohdan nettopoikkileikkauksen kestoikä on 24 työvuotta ja pituushitsin kestoikä 162 työvuotta, jos hitsi on sijoitettu vedetylle puolelle puristetun sijaan. Hitsiliitosten mitoituksessa huomattiin, että kriittisimpien liitosten suunniteltu kestoikä ei toteudu ilman hitsin jälkikäsittelyä. Mitoitustulokset esitetään kootusti taulukossa 5.

\section{Tulokset}

Kun runkoputket vaihdetaan lujuusluokan S355 teräksestä S700 teräkseen, voidaan teräksen määrää vähentää, jolloin runkorakenteiden massa pienenee oleellisesti. Rakenneputkien mitatun väsymisluokan mukaisesti mitoitettujen runkoputkien pitkittäinen hitsisauma ei muodostunut kriittiseksi oletusta korkeamman väsymisluokan ansiosta. Lisäksi liitosten uudelleensuunnittelulla ja hitsisaumojen jälkikäsittelyllä kriittisten kohtien kestoikä saadaan nostettua vähintään 15 työvuoden tasolle. Kriittisimmillä hitsisaumoilla suunnitellun käyttöiän saavuttaminen edellyttää hitsin 
jälkikäsittelyä. Suunnittelussa oletettiin levyosien materiaaliksi S355-lujuusluokan teräs, jolloin näiden osien massa ei pienentynyt. Mikäli nämä olisi työn rajauksesta huolimatta muutettu lujemmaksi materiaaliksi, olisi kokonaismassa todennäköisesti pienentynyt huomattavasti enemmän. Taulukossa 4 esitetään alkuperäisten -ja uusien rakenneosien massat sekä näiden erot. Taulukossa 5 esitetään alkuperäisten -ja uusien rakenneyksityiskohtien kestoiät sekä näiden erot. Alkuperäisen rakenteen päärungon nettopoikkileikkaukselle sekä päärungon pitkittäishitsille ei määritetty kestoikää. Alkuperäinen päärungon pitkittäishitsi on puristettu, jolloin sen ei oleteta väsyvän. Myös uuden päärungon pitkittäishitsi sijoitetaan puristuspuolelle, vaikka sen sijoittaminen vetojännityksen puolelle ei aiheuttaisi ongelmia pitkän kestoiän perusteella. Apurungon kestoiän huononeminen johtuu pääosin rungossa käytetystä ohuemmasta profiilista ja sen aiheuttamasta jännitysten kasvusta sekä jännitysten laskennassa käytettyjen liitososien geometrioista.

Taulukko 4. Rakenneosien massojen vertailu

\begin{tabular}{lllll}
\hline & Päärunko [kg] & Apurungot [kg] & Muut [kg] & Yhteensä [kg] \\
\hline Alkuperäinen & 84,2 & 65,6 & 224,4 & 374,2 \\
\hline Uusi & 63,6 & 42,4 & 243,6 & 349,2 \\
\hline Ero \% & -24 & -35 & 9 & -7 \\
\hline
\end{tabular}

Taulukko 5. Kestoiät ja niiden vertailu

\begin{tabular}{llllllll}
\hline & $\begin{array}{l}\text { Päärunko } \\
\text { reikä }\end{array}$ & $\begin{array}{l}\text { Päärunko } \\
\text { nettopl. }\end{array}$ & $\begin{array}{l}\text { Päärunko } \\
\text { pitk. hitsi }\end{array}$ & $\begin{array}{l}\text { Apurunko } \\
\text { pitk. hitsi }\end{array}$ & $\begin{array}{l}\text { Apurunko } \\
\text { poikkileik } \\
\text { kaus }\end{array}$ & $\begin{array}{l}\text { Apurunko } \\
\text {-päärunko } \\
\text { hitsiliitos }\end{array}$ & $\begin{array}{l}\text { Siivenkan } \\
\text { nattimen } \\
\text { hitsiliitos }\end{array}$ \\
\hline $\begin{array}{l}\text { Alkuperäi } \\
\text { nen }\end{array}$ & 25 & - & - & 2,2 & 999 & 17 & 0,7 \\
\hline Uusi & 25 & 24 & $-/ 162$ & 101 & 62 & 81 & 20 \\
\hline Ero \% & 0 & - & - & 4491 & -94 & 363 & 2757 \\
\hline
\end{tabular}

\section{Yhteenveto}

Ultralujia teräksiä käytettäessä rakenteen massaa saadaan pienennettyä tai kuormankantokykyä kasvatettua. Lujan teräksen käyttäminen vaatii kuitenkin erityisen huolellista suunnittelua rakenteiden ja liitosten muotoilun sekä lujuuslaskennan osalta. Rakenneosien liitosgeometrioiden vaikutukset rakenteen väsymiskestävyyteen ja kestoikään ovat merkittäviä. Hitsaus aiheuttaa liitettäviin teräksiin sekä mikro- että makrorakenteen muutoksia, jotka vaikuttavat liitoksen käyttäytymiseen ja kestävyyteen. Hitsauksen tilalla voidaan käyttää ruuviliitoksia, mutta tämä ei ole aina mahdollista esimerkiksi suurten ruuvien ja ruuvimäärien takia. Hitsauksen aiheuttamia puutteita voidaan paikata hitsin jälkikäsittelyillä, joilla saadaan jopa 1,1-3 -kertainen väsymiskestävyys käsittelemättömään verrattuna liitostyypistä ja käsittelymenetelmästä riippuen. Eri lähteistä löytyviä parannuskertoimia on käytettävä harkitusti, sillä kertoimet perustuvat väsytyskokeisiin, joita on vaikea tehdä täyden mittakaavan rakenteille kattavasti. Lujasta teräksestä valmistettujen konerakenteiden hitsien suunnittelusta ja 
jälkikäsittelystä tarvitaan kuitenkin vielä lisää tutkimusta, sillä suunnittelutietoutta on vielä saatavilla rajallisesti.

\section{Viitteet}

[1] R.L. Norton. Machine Design. An Integrated Approach. $2^{\text {nd }}$ edition. Prentice-Hall, Upper Saddle River, New Jersey, 2000.

[2] L.-P. Keränen. Kyntöauran rakenteiden ja kuormitusten analysointi. Oulun yliopisto, teknillinen tiedekunta, konetekniikka, 2016.

[3] T. Björk. Ultralujien terästen hitsausliitosten väsymislujuus. Lappeenrannan teknillinen yliopisto, teräsrakenteiden laboratorio, 2013.

[4] E. Niemi \& P. Tarjavuori. Hitsin väsymislujuuden parantaminen jälkikäsittelyllä. Lappeenrannan teknillinen korkeakoulu, 1995.

[5] R.H. Leggatt. Residual stresses in Welded Structures. International Journal of Pressure Vessels and Piping, 85 (3):144-151, 2008. doi:10.1016/j.ijpvp.2007.10.004

[6] H.M. Miekk-oja. Metallioppi. Teknillisten tieteiden akatemia, Kustannusosakeyhtiö Otava, Helsinki, 1960.

[7] T. Salmi \& S. Pajunen. Lujuusoppi. Pressus Oy, Klingendahl Paino Oy, Tampere, 2010.

[8] A. Hobbacher. Recommendations for Fatigue Design of Welded Joints and Components. IIW document IIW-1823-07, WRC Bulletin 520, Internal Institute of Welding (IIW), The Welding Research Council, Inc, New York, 2009.

[9] A.A. Bhatti, Z. Barsoum, H. Murakawa \& I. Barsoum. Influence of thermosmechanical material properties of different steel grades on welding residual stresses and angular distortion. Materials and Design, 65: 878-889, 2015. https://doi.org/10.1016/j.matdes.2014.10.019.

[10] Z. Barsoum. Residual stress analysis and fatigue of multi-pass welded tubular structures. Engineering Failure Analysis, 15(7): 863-874, 2008. https://doi.org/ 10.1016/j.engfailanal.2007.11.016.

[11] T.-L. Teng, C.-P. Fung, P.-H. Chang \& W.-C. Yang. Analysis of residual stresses and distortions in T-joint fillet welds. International Journal of Pressure Vessels and Piping, 78(8): 523-538, 2001. https://doi.org/10.1016/S0308-0161(01)00074-6.

[12] D. Radaj. Heat Effects of Welding. Springer-Verlag, Berlin, Heidelberg, 1992.

[13] H.C. Yildirim. Design aspects of high strength steel welded structures improfed by high frequency mechanical impact (HFMI) treatment. Doctoral dissertations 134/2013, Aalto University, School of Engineering, Department of Applied Mechanics, Mechanics of Materials.

[14] N.E. Dowling. Mechanical Behavior of Materials. Prentice Hall, Upper Saddle River, New Jersey, 1999.

[15] M. Airila, K. Ekman, P. Hautala, S. Kivioja, M. Kleimola, H. Martikka, J. Miettinen, E. Niemi, A. Ranta, J. Rinkinen, P. Salonen, A. Verho, M. Vilenius \& V. Välimaa. Koneenosien suunnittelu. 4.-5. painos. WSOYpro Oy, Helsinki, 2010.

[16] A. Nieslony. Determination of fragments of multiaxial service loading strongly influencing the fatigue of machine components. Mechanical Systems and Signal Processing, 23(8): 2712-2721, 2009. https://doi.org/10.1016/j.ymssp.2009.05.010. 
[17] SFS-EN 1993-1-9. Eurocode 3: Teräsrakenteiden suunnittelu. Osa 1-9: Väsyminen. Suomen standardisoimisliitto SFS, 2005.

[18] SFS 2378. Hitsaus. Väsyttävästi kuormitettujen teräsrakenteiden hitsausliitosten mitoitus ja lujuuslaskenta. Suomen standardisoimisliitto SFS, 1992.

[19] M. Wilén. Pituussuunnassa hitsatun rakenneputken väsymislujuus HF-hitsausta käytettäessä. Diplomityö. Lappeenrannan teknillinen yliopisto, Teknillinen tiedekunta, LUT Kone, Konstruktiotekniikan koulutusohjelma, 2014.

[20] J. Tuomaala. Koneensuunnitteluoppi, Osa 5 Ruuviliitokset. Oulun yliopisto, Koneensuunnittelun laboratorio, 1994.

[21] SFS-EN 1090-2. Teräs- ja alumiinirakenteiden toteutus. Osa 2: teräsrakenteita koskevat tekniset vaatimukset. Suomen standardisoimisliitto SFS, 2012.

[22] SSAB. Strenx tube 700 MH, datasheet, 2015.

[23] T. Nykänen \& T. Njörk. A new proposal for assessment of the fatigue strength of steel butt-welded joints improved by peening (HFMI) under constant amplitude tensile loading. Fatigue \&Fracture of Engineering Materials \& Structures, 39(5): 566-582, 2016. https://doi.org/10.1111/ffe.12377.

[24] A. Ahola. Effect of loading type on the fatigue strength of symmetric and asymmetric welded joints made of ultra high strength steel. Master's thesis. Lappeenranta University of Technology, LUT School of Energy Systems, LUT Mechanical Engineering, 2016.

Lassi Keränen

Oulun yliopisto

Teknillinen tiedekunta

Koneensuunnittelun tutkimusyksikkö

Erkki Koiso-Kanttilan katu 5, PL 4200

90014 Oulun yliopisto 